\title{
$1 \quad$ Clinical Outcomes and Complications of Pituitary Blastoma
}

2

3 Anthony P.Y. Liu ${ }^{1}$, Megan M. Kelsey ${ }^{2}$, Nelly Sabbaghian ${ }^{3}$, Sung-Hye Park $^{4}$, Cheri L. Deal ${ }^{5}$, Adam

4 J. Esbenshade ${ }^{6}$, Oswald Ploner ${ }^{7}$, Andrew Peet ${ }^{8,9}$, Heidi Traunecker ${ }^{10}$, Yomna H.E. Ahmed ${ }^{11}$,

$5 \quad$ Margaret Zacharin ${ }^{12}$, Anatoly Tiulpakov ${ }^{13}$, Anastasia M. Lapshina ${ }^{14}$, Andrew W. Walter ${ }^{15}$, Pinaki

6 Dutta $^{16}$, Ashutosh Rai ${ }^{16}$, Márta Korbonits ${ }^{17}$, Leanne de Kock ${ }^{18}$, Kim E. Nichols ${ }^{19}$, William D.

$7 \quad$ Foulkes $^{3,20}$, and John R. Priest ${ }^{21}$

8 1. Division of Neuro-Oncology, Department of Oncology, St. Jude Children's Research Hospital, $9 \quad$ Memphis, TN, USA

10 2. Department of Pediatrics, Section of Pediatric Endocrinology, Children's Hospital Colorado

11 and University of Colorado Anschutz Medical Campus, Aurora, CO, USA

12 3. Department of Medical Genetics and Cancer Research Program, Research Institute McGill

13 University Health Centre, Montreal, Quebec, Canada

14 4. Department of Pathology, Seoul National University, College of Medicine, Seoul, Republic of

$15 \quad$ Korea

16 5. Endocrinology and Diabetes Service, CHU-Sainte Justine and Department of Pediatrics,

17 University of Montreal, Montreal, QC, Canada

18 6. Department of Pediatrics, Monroe Carell Jr. Children's Hospital, Nashville, TN, USA

19 7. Diakonie-Klinikum, Stuttgart, Germany

20 8. Institute of Cancer and Genomic Sciences, University of Birmingham, Birmingham, United

$21 \quad$ Kingdom

22 9. Birmingham Children's Hospital NHS Foundation Trust, Birmingham, United Kingdom

23 10. Noah's Ark Children's Hospital for Wales, Cardiff, United Kingdom 
1 11. Royal College of Surgeons in Ireland - Bahrain, Bahrain

2 12. Department of Endocrinology and Diabetes, Royal Children's Hospital, Flemington Road,

$3 \quad$ Parkville, Melbourne, VIC, Australia

4 13. Department and Laboratory of Inherited Endocrine Disorders, Endocrinology Research Centre,

$5 \quad$ Moscow, Russia

6 14. Department of Fundamental Pathomorphology, Endocrine Research Centre, Moscow, Russia

7 15. duPont Hospital for Children, Wilmington, DE, USA

8 16. Department of Endocrinology, Post Graduate Institute of Medical Education and Research,

$9 \quad$ Chandigarh, India

10 17. Department of Endocrinology, Barts and the London School of Medicine, Queen Mary

11 University of London, London, UK, EC1M 6BQ

12 18. Harry Perkins Institute of Medical Research, QEII Medical Centre and UWA Centre for

13 Medical Research, the University of Western Australia, Perth, Australia

14 19. Division of Cancer Predisposition, Department of Oncology, St Jude Children's Research

15 Hospital, Memphis, TN, USA

16 20. Department of Medical Genetics, The Lady Davis Institute, Segal Cancer Centre, Jewish

17 General Hospital, Montreal, Quebec, Canada H3T 1E2

18 21. Minneapolis, MN, 55414 USA

19

20 Running title: Pituitary blastoma

21

22 Key Words: Pituitary blastoma, endocrinopathy, DICER1, microRNA, infants, morbidities 
1 Corresponding author: Anthony P.Y. Liu, MBBS, MMedSc; MS 260, St. Jude Children's

2 Research Hospital, 262 Danny Thomas Place, Memphis, TN 38105-3678; tel (901) 595-5898; fax

3 (901) 521-9005; anthony.liu@stjude.org

4

5 Funding: This work was sponsored by the American Lebanese Syrian Associated Charities

6 (A.P.Y.L., K.E.N.) and the Canadian Institutes of Health Research (FDN-148390) (W.D.F.)

7

8 Disclosure Statement: The authors have nothing to disclose. 


\section{$1 \quad$ Abstract}

2 Context: Pituitary blastoma is a rare, dysontogenetic hypophyseal tumor of infancy first described

3 in 2008, strongly suggestive of DICER1 syndrome.

4 Objective: To describe genetic alterations, clinical courses, outcomes, and complications in all

$5 \quad$ known pituitary blastoma cases.

6 Design and Setting: Multi-institutional case series from tertiary pediatric oncology centers.

$7 \quad$ Patients: Children with pituitary blastoma.

8 Interventions: Genetic testing, surgery, oncologic therapy, endocrine support.

9 Outcome Measures: Survival, long-term morbidities, germline and tumor DICER1 genotypes.

10 Results: Seventeen pituitary blastoma cases were studied (10 female and 7 male); median age at

11 diagnosis was 11 months (range 2-24). Cushing syndrome was the most frequent presentation

12 (n=10). Cushingoid stigmata were absent in seven children (two with raised ACTH; five with

13 normal/unmeasured ACTH). Ophthalmoplegia and increased intracranial pressure were also

14 observed. Surgical procedures included gross/near-total resection $(n=7)$, subtotal resection $(n=9)$,

15 and biopsy $(n=1)$. Six children received adjuvant therapy. At a median follow-up of 6.7 years, nine

16 patients were alive; eight patients died of early medical/surgical complications $(n=3)$, sepsis $(n=1)$,

17 catheter-related complication $(n=1)$, aneurysmal bleeding $(n=1)$, second brain tumor $(n=1)$, and

18 progression $(n=1)$. Surgery was the only intervention for five of nine survivors. Extent of resection,

19 but neither Ki67 labelling index nor adjuvant therapy, was significantly associated with survival.

20 Chronic complications included neuroendocrine $(n=8)$, visual $(n=4)$, and neurodevelopmental

21 (n=3) deficits. Sixteen pituitary blastomas were attributed to DICER1 abnormalities. 
1 Conclusions: Pituitary blastoma is a locally destructive tumor associated with high mortality.

2 Surgical resection alone provides long-term disease control for some patients. Quality survival is 3 possible with long-term neuroendocrine management.

4 


\section{Introduction}

2 Pituitary blastoma is a distinctive anterior hypophyseal tumor of infants described first in 2008 (1).

3 While the clinical, pathological, and molecular features of 14 cases have been described (1-4),

4 there are no comprehensive data on long-term outcomes. Pituitary blastoma presents in infants

5 under 24 months of age, most frequently with Cushing syndrome and elevated adrenocorticotropic

6 hormone (ACTH) and occasionally with ophthalmoplegia, signs of increased intracranial pressure,

7 diabetes insipidus, and thyrotropin deficit. An often large solid or cystic/solid mass arises from the

8 sella with extension into the hypothalamus and may encompass the optic chiasm and/or cavernous

9 sinuses. Pathologically, the tumors exhibit arrested pituitary development and uncontrolled

10 proliferation and are composed of Rathke's epithelium, folliculostellate cells, small primitive cells,

11 and secretory cells with ACTH or, less often, growth hormone (GH) immunoexpression $(2,4)$.

12

13 Pituitary blastoma is highly indicative of DICER1 syndrome, as all reported, completely-studied

14 cases can be tied to DICERl abnormalities (3-5). DICER1 syndrome is caused by alterations in

15 the microRNA processing gene DICER1, typically from inherited heterozygous pathogenic

16 alterations, including single nucleotide variants and large or small insertions or deletions; de novo

17 germline alterations and mosaicism also occur $(5,6)$. DICERl is critical for the biogenesis of

18 microRNAs, which modulate gene expression by inhibition of messenger RNA. Virtually all

19 DICER1 syndrome tumors harbor a characteristic somatic change in the second DICERI allele-

20 a so-called RNase IIIb "hotspot mutation," affecting one of five critical ion-binding sites in the

21 cleavage domain of the DICER1 protein (5). In a minority of pituitary blastomas, the somatic event

22 is not the usual hotspot mutation but instead a loss of the wild-type allele (4). 
1 Other phenotypes of DICER1 syndrome that may present with symptoms of possible

2 endocrinologic disease include ovarian Sertoli-Leydig cell tumor, sarcoma of the uterine cervix

3 with vaginal bleeding, and several thyroid proliferations: multinodular goiter, familial

4 multinodular goiter, and differentiated thyroid cancer (7-11). The latter is usually a moderate or

5 well differentiated tumor with excellent outcomes, but a potentially lethal poorly differentiated

6 DICER1-related subtype has recently emerged in adolescents (12). In addition to thyroid and

7 gynecologic conditions, DICER1 syndrome includes approximately 25 conditions in other organ

8 systems. Most phenotypes are proliferative mesenchymal masses, both malignant and benign (5),

9 and several affect very young children, such as pituitary blastoma, pleuropulmonary blastoma,

10 cystic nephroma and certain other very rare intracranial neoplasms $(13,14)$. Penetrance in DICER1

11 syndrome is generally low: $<5-10 \%$ for the more frequent phenotypes and $<1 \%$ for the rare

12 phenotypes such as pituitary blastoma (15). However, multinodular goiter, which has no specificity

13 for DICER1 syndrome, is estimated to affect $75 \%$ of female and $17 \%$ of male carriers of DICER1

14 mutations (9). Also, occult, asymptomatic lung cysts detected by computerized tomography have

15 been demonstrated in $25-30 \%$ of mutation carriers (15).

\section{6}

17 Here, we report the long-term outcomes of all known, well-investigated cases of pituitary blastoma

18 including three cases not previously published in detail (16-18). A recent brief report of a possible

19 18th case in a 19-year-old female is not included (19). Patient presentation, oncologic treatments, 20 updated clinical outcomes, genetic profiles, and morbidities including neuroendocrine 21 complications are detailed.

22

\section{Materials and Methods}




\section{Design and Study Cohort}

2 This observational study comprised a multi-institutional cohort of 17 patients with pituitary

3 blastoma: updating 14 previously described cases (1-4,20-28) and fully characterizing three

4 additional cases (16-18). Cases were identified by ongoing literature review, inquiries to leading

5 pituitary experts and case referrals. Cases were included based on clinical findings, pathological

6 diagnosis, and DICER1 molecular findings or on prototypical DICER1 syndrome phenotypes in

7 the child. Retrospective chart review was performed to collect demographic, clinical, biochemical,

8 pathological, radiographic, and treatment characteristics. The chart review also updated patient

9 outcomes including tumor progression, patient survival, and in survivors, long-term health deficits

10 focusing on endocrinologic, visual, and neurodevelopmental morbidities. Molecular and

11 immunohistochemical data from primary institutions were recorded. Molecular studies were

12 performed on one case (Case 17) not previously studied. The study was approved by the respective

13 institutional review boards of participating institutions, with informed consent obtained in

14 accordance with institutional guidelines.

\section{DICERI Genotyping}

16 DICER1 genotyping has been previously reported for 14 cases $(3,4,17,18)$. Sequencing of DICERI

17 was performed on Case 17 by using the custom-design Access Array (Fluidigm), and an exon

18 trapping assay was used to validate the functional consequence of a newly identified splice-site

19 variant $(4,29,30)$. In two cases, no molecular information was available, but one of the cases

20 showed strong clinical evidence of DICER1 syndrome (4).

\section{Survival Analyses}


1 The date of diagnosis was defined as the date of first biopsy or resection. Overall survival (OS)

2 was defined as the duration between the date of diagnosis and date of either death from any cause

3 or last follow-up. Event-free survival (EFS) was defined as the duration between the date of

4 diagnosis and date of progression, relapse, death from any cause, or last follow-up. Comparison of

5 OS and EFS by clinical factors (extent of resection, use of adjuvant therapy, year of diagnosis)

6 was performed by log-rank test. Data collection was closed on April 30, 2020. Statistical analyses

7 were performed using R v3.6.0 (www.R-project.org).

8

\section{Results}

10 Recently Investigated Cases of Pituitary Blastoma

11 Since the reports by Sahakitrungruang et al. (1 case) and de Kock et al. (13 cases), three additional

12 cases of pituitary blastoma have been thoroughly investigated (1-4,16-18,20-28). In 2010, Salunke

13 et al. reported a 2-month-old female with Cushingoid stigmata since birth, ophthalmoplegia,

14 hemiparesis, and a pituitary tumor diagnosed as a "congenital immature teratoma" (Case 17; Table

15 1) (30,31); the pathology on review was consistent with pituitary blastoma (16). We subsequently

16 studied DNA from tumor and germline DNA from the parents and two siblings. The patient and

17 siblings inherited a splice-site DICERI variant from the father; splicing studies revealed that the

18 variant creates an out-of-frame nucleotide sequence predicted to result in a truncated protein,

19 which may be subject to nonsense-mediated decay (30). Despite poor-quality tumor DNA, an

20 RNase IIIb hotspot mutation was weakly, but reproducibly, detected. In a 2015 abstract, Gresh et

21 al. reported pituitary blastoma in a 22-month-old male with headaches and vomiting (17). A

22 DICER1 hotspot mutation was found in the tumor tissue, with loss of heterozygosity (LOH)

23 suggested; a germline pathogenic variant could not be identified in DNA extracted from peripheral 
1 blood lymphocytes (Case 16; Table 1) (30,31). In a 2017 abstract, Kalinin et al. reported pituitary

2 blastoma in a 10-month-old male with Cushing disease and a past medical history of cystic lung

3 dysplasia; the primary investigators documented somatic hotspot and inherited germline DICER1

4 pathogenic variants (Case 15; Table 1) $(18,30,31)$.

\section{Demographic and Presenting Features of the Entire Cohort}

6 Seventeen patients were reported between 1979 and 2017; 10 were female (Table 1). First

7 symptoms were noted at a median age of 8.5 months (range 0-22 months); median age of diagnosis

8 was 11 months (range 2-24 months). Presenting symptoms included Cushing syndrome $(\mathrm{n}=10)$,

9 cranial nerve palsies including ophthalmoplegia $(n=7)$, reduced visual acuity $(n=4)$, developmental

10 delay $(n=4)$, and symptoms of raised intracranial pressure $(n=3)$. Increased ACTH $(n=9)$ or random

11 serum cortisol $(n=1)$ was documented at diagnosis in the 10 patients presenting with Cushing

12 syndrome (Table 2). Figure 1 presents growth charts for three cases, including a classic pattern for

13 Cushing syndrome as the weight plot rises to cross the falling length plot (Figure 1B).

14 Preoperatively, among the seven children without signs of Cushing syndrome at diagnosis (Table

15 2), assays revealed one child with normal ACTH and two with increased ACTH (one coupled with

16 unsuppressed morning cortisol and one with a normal random serum cortisol). ACTH or

17 serum/urine cortisol was not done in four patients. These patients presented with ophthalmoplegia

$18(n=4)$ or symptoms of raised intracranial pressure $(n=3)$. Before surgery, secondary

19 hypothyroidism was noted in three patients and diabetes insipidus in two. Immunohistochemical

20 staining for ACTH was positive in 16 of 17 tumors; the patient whose tumor was negative for

21 ACTH presented with signs of increased intracranial pressure, and no endocrinologic assessment

22 was done preoperatively. Immunohistochemistry for GH was positive in 10 of the 14 cases tested,

23 but serum IGF1 (n=3) and spot GH $(n=1)$ did not suggest GH excess in the four patients evaluated 
1 (Table 2). At presentation, no child exhibited excessive linear growth, although in the presence of

2 Cushing disease clinical change due to excess GH would have been hard to discern. In contrast to

3 the $\mathrm{ACTH}$ and $\mathrm{GH}$ findings, tumor immunostains for other pituitary hormones were rarely

4 positive: luteinizing hormone, $1 / 10$; follicle stimulating hormone, 1/11; thyroid stimulating

5 hormone, 0/10; and prolactin, 0/10. Radiographically, an enhancing sellar mass, with or without

6 intratumoral cysts and cavernous sinus involvement, was typically seen on magnetic resonance

7 imaging, with a median greatest diameter of $3 \mathrm{~cm}$ (range 1.7-12 cm) (31); enhancement was not

8 seen in one patient. None of the patients showed metastasis at diagnosis or during follow-up.

\section{$9 \quad$ Treatments and Outcomes}

10 Patient treatments and outcomes are summarized in Table 1 and Figure 2. Surgical resection was

11 attempted at diagnosis in all patients, including four patients who had staged resection, resulting

12 in gross or near-total resection (GTR/NTR, $n=7)$, subtotal resection $(\mathrm{STR}, \mathrm{n}=9)$, and biopsy $(\mathrm{Bx}$,

$13 \mathrm{n}=1$ ). Five patients received chemotherapy after surgery (Table 1). Two patients received focal

14 radiation: gamma-knife radiotherapy 17 months after diagnosis for persistent residual disease

15 (Case 2), and conformal radiation 24 months after the diagnosis of disease progression (Case 5;

16 Table 1).

17 Four patients died within six weeks of surgery from medical/surgical complications $(\mathrm{n}=3)$ or sepsis

$18(\mathrm{n}=1)$; four died later in their courses from a second brain tumor (

19 central venous catheter related complication $(n=1)$, aneurysmal bleeding $(n=1)$, or progression

$20(\mathrm{n}=1)$ (Figure 2). The patient who died from aneurysmal bleeding (Case 5) had also had local

21 progression that was treated with conformal radiation (54 Gy, at age 37 months) and three lines of

22 chemotherapy including bevacizumab (Table 1). The patient died six months from the last

23 documented progression; autopsy was not performed and tumor status at death is unknown. 
1 At a median follow-up of 6.7 years (range 1 day to 23.5 years), nine patients are alive without

2 evidence of disease $(n=7)$ or stable residual lesion radiographically $(n=2$, duration of follow-up:

38.2 and 10 years) (Table 1, Figure 2) (31). Of the seven surgery-only patients who survived beyond

46 weeks, five were long-term survivors; their extents of surgery were, respectively, GTR $(n=4)$

5 and STR $(n=1)$ (Figure 2). The 5-year EFS and OS were 53 $\pm 12 \%$ and $59 \pm 12 \%$, respectively

6 (Figure 3). Extent of resection (GTR/NTR vs. STR/Bx; EFS p=0.018, OS p=0.023) and year of

7 diagnosis (before 1996 vs. 1996 or later; EFS p=0.048, OS p=0.02), were significantly associated

8 with patient survival. Neither use of adjuvant therapy nor tumor Ki67 labelling index was

9 significantly associated with survival. Although not statistically significantly associated with

10 better outcomes across all cases, chemotherapy in Case 3 was temporally associated with an

11 improvement in recrudescent hypercortisolemia three months following surgery (discussed

12 below).

13 Endocrinologic, Visual, and Neurodevelopmental Morbidities

14 Chronic health deficits were noted in the eight of the nine survivors. Hypopituitarism was frequent

15 (Table 2). Deficiencies were noted in ACTH $(n=7)$, thyrotropin $(n=7)$, gonadotropin $(n=4)$,

16 antidiuretic hormone $(\mathrm{n}=3)$, and $\mathrm{GH}(\mathrm{n}=6)$. GH replacement was administered to all patients with

17 documented GH deficiency (initiated at age 2.3-13.1 years, and 0.3-7.3 years from oncological

18 diagnosis) (Figure 1B). One survivor (Case 12) aged 8.9 years was not evaluated for GH status

19 and was $101 \mathrm{~cm}$ tall, 5.6 standard deviations below the mean for age (Figure 1C); this child

20 received neither $\mathrm{GH}$ nor other hormonal supplementation. Persistent hypercortisolism was not

21 observed among long-term survivors. In Case 3, cortisol levels progressively diminished in the

22 first three months following STR of tumor. At four months, hypercortisolemia returned and the

23 child started to become Cushingoid. Chemotherapy was commenced, with cortisol measurements 
1 normalizing over the next 12-18 months. At 10 years from diagnosis, a small, stable residual lesion

2 at the right cavernous sinus remained, and the child was thriving well without endocrinopathy

3 (Figure 1A) (31). Four patients had visual complications: severe vision impairments $(\mathrm{n}=2)$,

4 extraocular movement palsy $(n=1)$, and bilateral optic atrophy as well as extraocular movement

5 palsy $(n=1)$. Neurodevelopmentally, six patients were reported to be progressing satisfactorily in

6 academic studies, whereas two patients had cognitive delay. The patient who received gamma-

7 knife therapy had Moyamoya disease that required revascularization surgery 9.3 years after

8 radiation.

9 Genotyping and DICER1 Syndrome

10 Genotyping results for the patients and for the pituitary blastomas and additional DICER1

11 syndrome conditions in the patients are available in an online repository (30). Germline DICERI

12 variants were detected in 12 of 13 patients tested. DICERl alterations were identified in 13 of 14

13 tumor samples tested (hotspot mutations, $\mathrm{n}=11 ; \mathrm{LOH}, \mathrm{n}=2$ ). In no case did we have proof that both

14 the hotspot and non-hotspot DICER1 abnormalities detected in tumor DNA were somatic in origin.

15 One child for whom DNA was unavailable had strong clinical evidence of DICERI involvement

16 (bilateral renal and pulmonary cysts) (21-23). For one child, the clinical history was unremarkable

17 and DNA was unavailable. Overall, molecular and/or clinical evidence implicates DICERI in 16

18 of the 17 pituitary blastoma cases.

19 In six of eight patients whose families underwent testing, the predisposing DICERI variant in the

20 index patient was found to be inherited. Members of five of the six families had DICER1-related

21 conditions (30). Among pituitary blastoma survivors (median age at last follow-up 10.8 years,

22 range 8.5-24.1 years), one patient was subsequently diagnosed with an additional DICER1

23 syndrome-related condition (Case 11, nasal chondromesenchymal hamartoma). Among the non- 
1 survivors, one child developed a second DICER1 condition: a primitive neuroectodermal tumor in

2 the pineal region considered likely pineoblastoma, which was considered the cause of death.

3

\section{Discussion}

5 Pituitary blastoma is a rare intracranial tumor typified by onset under age 24 months, Cushing

6 disease and a strong association with abnormalities of DICER1. This study summarizes 17 cases

7 and describes long-term outcomes and morbidities. Follow-up clinical data were available from

8 all surviving patients. Biochemical evidence of hypercortisolism was present in the 10 infants who

9 presented with Cushingoid stigmata; 16 of 17 tumors stained for ACTH. Sixteen of the 17 cases

10 can be tied to abnormalities of gene DICERI. Nine of 17 patients survive (median survival 6.7

11 years; median age at last follow-up 10.8 years) with hormonal sequalae ranging from none to

12 panhypopituitarism and neurocognitive function ranging from fully functional to impaired, and

13 some survivors were visually impaired. GH replacement therapy in several children was not

14 associated with disease recurrence or development of other neoplasms, in keeping with

15 recommendations for judicious use of GH replacement in cancer survivors $(32,33)$.

16

17 Six complication-related deaths in the cohort compromise the study of long-term outcomes and

18 potential prognostic factors (Table 1; Figure 2). Three early deaths occurred in infants with

19 Cushing disease, a potentially life-threatening endocrine condition (34), and highlight the

20 medical/surgical challenge caring for a small infant with an intracranial mass and a serious

21 endocrine disturbance. Notwithstanding limited case numbers, our analyses (Figure 3) suggest that

22 GTR/NTR are beneficial and that more recently treated cases are associated with better survival,

23 which seems reasonable given advances in imaging, neurosurgery, intensive care and 
1 endocrinology. Five of seven children whose only intervention was surgery were long term

2 survivors. Adjuvant therapy was not significantly associated with better survival. This contrasts

3 with high-grade pediatric brain tumors, which are likely to recur unless adjuvant therapies are

4 used.

5

6 Vascular complications (aneurysm and Moyamoya disease) occurred in the two children (Table 1,

7 Figure 2) who received intensive focal radiation therapy, echoing risk factors for post-radiation

8 vasculopathy identified in young children treated for craniopharyngioma or optic pathway glioma:

9 age $<5$ years, radiation dose $>50 \mathrm{~Gy}$, and radiation field involving the Circle of Willis $(35,36)$. The

10 aneurysm in Case 5 may also have been associated with prior surgery ("pseudoaneurysm") (37).

11 These data suggest that radiation therapy for pituitary blastoma must be considered with special

12 caution.

\section{3}

14 Cushing disease presenting in an infant suggests pituitary blastoma; other characteristic lesions in

15 the patient, or a family history of DICER1 phenotypes, strengthens the possibility $(3,38)$. A

16 pathologic diagnosis of pituitary blastoma should prompt genetic testing of the affected infant after

17 parental informed consent, and in the tumor for DICER1 alterations. The results will dictate the

18 need for genetic counselling and investigation of the family. A separate issue is the wisdom of

19 screening an infant known to harbor DICER1 alterations for presymptomatic pituitary blastoma;

20 this would require head MR imaging with anesthesia in the first 24 months of life, perhaps more

21 than once. Due to its rarity as a DICER1 phenotype, the authors do not believe the risk-benefit

22 ratio justifies such screening. We prefer genetic counselling and parental education as the best 
1 approach to helping families adjust to the possibilities of pituitary blastoma as well as the multiple

2 other phenotypes in DICER1 syndrome. A counter argument in favor of central nervous system

3 screening could be made in that several different intracranial neoplasms in young children can

4 occur in DICER1 syndrome (discussed below); however, all are very rare phenotypes. General

5 discussions of screening strategies in DICER1 syndrome have been published $(5,39,40)$.

6

7 In 2014, de Kock et al. expressed uncertainty about whether pituitary blastoma is a truly malignant

8 tumor (4). Despite the "blastoma" designation and primitive histologic features, which recapitulate

9 the embryologic pituitary, pituitary blastoma appears mostly to be a locally aggressive tumor;

10 metastases have not been observed at diagnosis or in follow-up. Although the behavior of pituitary

11 blastoma remains to be clarified, our findings suggest that progression is not typical and that

12 observation of these very young patients may be prudent after satisfactory resection. Perhaps

13 proliferation of pituitary blastoma is limited to a certain age range, similar to other DICER1

14 phenotypes such as pleuropulmonary blastoma and cystic nephroma, which occur almost

15 exclusively from ages $0-72$ and $0-48$ months, respectively (5). Multinodular goiter in DICER1

16 syndrome occurs at earlier ages than in the general population and also exhibits a strong

17 predilection for females (9). DICER1-related gynecologic tumors (ovary, uterus and fallopian

18 tube) typically occur between ages 10 and 25 years, with some variation. The biological basis for

19 the reported biases in DICER1 syndrome, for example, age of onset, goiter in females, and the

20 propensity for gynecologic disease, are not understood. Age-confined presentations occur in other

21 genetic disorders with endocrinologic features: in McCune-Albright syndrome, primary

22 hypercortisolism presents during infancy and might abate spontaneously with age; in Carney 
1 complex, osteochondromyxoma present typically before age 2 years and has been reported at birth,

2 and nodular thyroid disease often appears by age 10 years (41-43).

3

4 Pituitary blastoma is only one of several intracranial tumors associated with DICER1 syndrome,

5 including pineoblastoma, DICER1-mutant primary intracranial sarcoma, embryonal tumor with

6 multilayered rosettes, and pleuropulmonary blastoma metastasis (13,39,44-51). Indeed, the

7 quickly fatal second tumor in the region of the pineal gland in Case 7 was radiographically

8 considered a recurrence of pituitary blastoma, but at autopsy was revealed pathologically to be a

9 primitive neuroectodermal tumor, which we interpret was likely a pineoblastoma, now recognized

10 to occur in DICER1 syndrome.

11

12 In conclusion, we report the clinical features, molecular profiles and outcome of 17 patients with

13 pituitary blastoma, a distictive phenotype of DICER1 syndrome. The rarity of pituitary blastoma

14 and limited sample size hamper robust analyses of demographic and therapy-related prognostic

15 factors, although it appears that complete or near complete surgical resection may be adequate for

16 disease control in some patients and that extensive endocrinologic support is needed. Our

17 description of the typical disease course and long-term outlook for children with pituitary blastoma

18 will serve as a useful resource for physicians and families.

19

20 Acknowledgements

21 
1 The authors acknowledge the families who have allowed their cases to be shared and analyzed.

2 We also thank the medical teams from all participating institutions for providing exceptional care

3 for these patients. We express our gratitude to Steffen Albrecht, MD, Department of Pathology,

4 McGill University for providing expertise on pathology review, Eric Carolan, MD for his

5 neuroradiologic expertise. We thank Vani Shanker, PhD, ELS for editing the manuscript.

6 
1. Scheithauer BW, Kovacs K, Horvath E, Kim DS, Osamura RY, Ketterling RP, Lloyd RV, Kim OL. Pituitary blastoma. Acta Neuropathol. 2008;116(6):657666.

2. Scheithauer BW, Horvath E, Abel T, Robital Y, Park S-H, Osamura R, Deal C, Lloyd R, Kovacs K. Pituitary blastoma: a unique embryonal tumor. Pituitary. 2012;15(3):365-373.

3. Sahakitrungruang $T$, Srichomthong $C$, Pornkunwilai S, Amornfa J, Shuangshoti S, Kulawonganunchai S, Suphapeetiporn K, Shotelersuk V. Germline and somatic DICER1 mutations in a pituitary blastoma causing infantile-onset Cushing's disease. $J$ Clin Endocrinol Metab. 2014;99(8): E1487-E1492.

4. De Kock L, Sabbaghian N, Plourde F, Srivastava A, Weber E, Bouron-Dal Soglio D, Hamel N, Choi JH, Park S-H, Deal CL, Kelsey MM, Dishop MK, Esbenshade A, Kuttesch JF, Jacques TS, Perry A, Leichter H, Maeder P, Brundler MA, Warner J, Neal J, Zacharin M, Korbonits M, Cole T, Traunecker H, McLean TW, Rotondo F, Lepage P, Albrecht S, Horvath E, Kovacs K, Priest JR, Foulkes WD. Pituitary blastoma: a pathognomonic feature of germ-line DICER1 mutations. Acta Neuropathol. 2014;128(1):111-122.

5. Foulkes WD, Priest JR, Duchaine TF. DICER1: mutations, microRNAs and mechanisms. Nat Rev Cancer. 2014;14(10):662.

6. de Kock L, Wang YC, Revil T, Badescu D, Rivera B, Sabbaghian N, Wu M, Weber E, Sandoval C, Hopman SM. High-sensitivity sequencing reveals multi-organ somatic mosaicism causing DICER1 syndrome. J Med Genet. 2016;53(1):4352.

7. Schultz KAP, Harris A, Doros LA, Young RH, Dehner LP, Frazier AL, Hill DA, Messinger YH. Clinical and genetic aspects of ovarian stromal tumors: A report from the International Ovarian and Testicular Stromal Tumor Registry. J Clin Oncol. 2014;32(15_suppl):5520.

8. Doros L, Yang J, Dehner L, Rossi CT, Skiver K, Jarzembowski JA, Messinger Y, Schultz KA, Williams G, André N. DICER1 mutations in embryonal rhabdomyosarcomas from children with and without familial PPB-tumor predisposition syndrome. Pediatr Blood Cancer. 2012;59(3):558-560.

9. Khan NE, Bauer AJ, Schultz KAP, Doros $L$, Decastro RM, Ling A, Lodish MB, Harney LA, Kase RG, Carr AG, Rossi CT, Field A, Harris AK, Williams GM, Dehner LP, Messinger YH, Hill DA, Stewart DR. Quantification of thyroid cancer and multinodular goiter risk in the DICER1 syndrome: a family-based cohort study. J Clin Endocrinol Metab. 2017;102(5):1614-1622.

10. de Kock L, Sabbaghian N, Soglio DB, Guillerman RP, Park BK, Chami R, Deal CL, Priest JR, Foulkes WD. Exploring the association Between DICER1 mutations and differentiated thyroid carcinoma. J Clin Endocrinol Metab. 2014;99(6):E1072-1077.

11. Choong CS, Priest JR, Foulkes WD. Exploring the endocrine manifestations of DICER1 mutations. Trends Mol Med. 2012;18(9):503-505.

12. Chernock RD, Rivera B, Borrelli N, Hill DA, Fahiminiya S, Shah T, Chong A-S, Aqil B, Mehrad M, Giordano TJ, Sheridan R, Rutter MM, Dehner LP, Foulkes WD, Nikiforov YE. Poorly differentiated thyroid carcinoma of childhood and adolescence: a distinct entity characterized by DICER1 mutations. Mod Pathol. 2020;33(7):1264-1274.

13. de Kock L, Priest JR, Foulkes WD, Alexandrescu S. An update on the central nervous system manifestations of DICER1 syndrome. Acta Neuropathol. 2019;139(4):689-701. 
14. de Kock L, Wu MK, Foulkes WD. Ten years of DICER1 mutations: Provenance, distribution, and associated phenotypes. Hum Mutat. 2019;40(11):19391953.

15. Stewart DR, Best AF, Williams GM, Harney LA, Carr AG, Harris AK, Kratz CP, Dehner LP, Messinger YH, Rosenberg PS, Hill DA, Schultz KAP. Neoplasm Risk Among Individuals With a Pathogenic Germline Variant in DICER1. J Clin Oncol. 2019;37(8):668-676.

16. Salunke $P$, Bhansali A, Dutta $P$, Bansal A, Gupta $K$, Vasishta RK, Singh $P$, Mukherjee KK. Congenital immature teratoma mimicking Cushing's disease. Pediatr Neurosurg. 2010;46(1):46-50.

17. Gresh $\mathbf{R}$, Piatt J, Walter A. A report of a child with a pituitary blastoma and DICER1 syndrome. Pediatr Blood Cancer. 2015;62:70-71.

18. Kalinin A, Strebkova N, Tiulpakov A, Vasiliev E, Petrov V, Kolodkina A, Kareva $M$, Mazerkina $\mathbf{N}$, Peterkova V. A novel DICER1 gene mutation in a 10-monthold boy presenting with ACTH-secreting pituitary blastoma and lung cystic dysplasia. Paper presented at: 19th European Congress of Endocrinology 2017; Lisbon. Endocrine Abstracts. 2017;49:EP1025.

19. Chhuon Y, Weon YC, Park G, Kim M, Park JB, Park SK. Pituitary Blastoma in a 19-Year-Old Woman: A Case Report and Review of Literature. World Neurosurg. 2020;139:310-313.

20. Moriarty M, Hoe F. Cushing disease in a toddler: not all obese children are just fat. Curr Opin Pediatr. 2009;21(4):548-552.

21. Sumner T, Volberg F. Cushing's syndrome in infancy due to pituitary adenoma. Pediatr Radiol. 1982;12(2):81-83.

22. Pullins $D$, Challa V, Marshall $R$, Davis Jr C. ACTH-producing pituitary adenoma in an infant with cysts of the kidneys and lungs. Histopathology. 1984;8(1):157-163.

23. Levy SR, Wynne CV, Lorentz WB. Cushing's syndrome in infancy secondary to pituitary adenoma. Am J Dis Child. 1982;136(7):605-607.

24. Miller WL, Townsend JJ, Grumbach MM, Kaplan SL. An infant with Cushing's disease due to an adrenocorticotropin-producing pituitary adenoma. $J$ Clin Endocrinol Metab. 1979;48(6):1017-1025.

25. List JV, Sobottka S, Hübner A, Bonk C, Koy J, Pinzer T, Schackert G. Cushing's disease in a 7-month-old girl due to a tumor producing adrenocorticotropic hormone and thyreotropin-secreting hormone. Pediatr Neurosurg. 1999;31(1):7-11.

26. Maeder P, Gudinchet F, Meuli R, Rilliet B, Theintz G. Cushing's disease due to a giant pituitary adenoma in early infancy: CT and MRI features. Pediatr Radiol. 1996;26(1):48-50.

27. Min HS, Lee SJ, Kim SK, Park SH. Pituitary adenoma with rich folliculo-stellate cells and mucin-producing epithelia arising in a 2-year-old girl. Pathol Int. 2007;57(9):600-605.

28. Wildi-Runge $S$, Bahubeshi A, Carret A, Crevier L, Robitaille $Y$, Kovacs $K$, Horvath E, Scheithauer B, Foulkes W, Deal C. New phenotype in the familial DICER1 tumor syndrome: pituitary blastoma presenting at age 9 months. Endocr Rev. 2011;32(03):P1-P777.

29. Tompson SW, Young TL. Assaying the Effects of Splice Site Variants by Exon Trapping in a Mammalian Cell Line. Bio Protoc. 2017;7(10).

30. Liu APY, Kelsey M, Sabbaghian N, Park S-H, Deal CL, Esbenshade AJ, Ploner O, Peet A, Traunecker H, Ahmed YHE, Zacharin M, Tiulpakov A, Lapshina AM, Walter AW, Dutta P, Rai A, Korbonits M, de Kock L, Nichols KE, Foulkes WD, Priest JR. Data from: Clinical Outcomes and Complications of Pituitary 
Blastoma. Figshare.2020. Deposited August $6 \quad 2020$. https://doi.org/10.6084/m9.figshare.12749846.

31. Liu APY, Kelsey M, Sabbaghian N, Park S-H, Deal CL, Esbenshade AJ, Ploner O, Peet A, Traunecker H, Ahmed YHE, Zacharin M, Tiulpakov A, Lapshina AM, Walter AW, Dutta P, Rai A, Korbonits M, de Kock L, Nichols KE, Foulkes WD, Priest JR. Data from: Clinical Outcomes and Complications of Pituitary Blastoma. Figshare.2020. Deposited August $6 \quad 2020$. https://doi.org/10.6084/m9.figshare.12749849.

32. Raman S, Grimberg A, Waguespack SG, Miller BS, Sklar CA, Meacham LR, Patterson BC. Risk of Neoplasia in Pediatric Patients Receiving Growth Hormone Therapy--A Report From the Pediatric Endocrine Society Drug and Therapeutics Committee. J Clin Endocrinol Metab. 2015;100(6):2192-2203.

33. Patterson BC, Chen Y, Sklar CA, Neglia J, Yasui Y, Mertens A, Armstrong GT, Meadows A, Stovall M, Robison LL, Meacham LR. Growth hormone exposure as a risk factor for the development of subsequent neoplasms of the central nervous system: a report from the childhood cancer survivor study. $J$ Clin Endocrinol Metab. 2014;99(6):2030-2037.

34. Gkourogianni A, Lodish MB, Zilbermint M, Lyssikatos C, Belyavskaya E, Keil MF, Stratakis CA. Death in pediatric Cushing syndrome is uncommon but still occurs. Eur J Pediatr. 2015;174(4):501-507.

35. Hall MD, Bradley JA, Rotondo RL, Hanel R, Shah C, Morris CG, Aldana PR, Indelicato DJ. Risk of Radiation Vasculopathy and Stroke in Pediatric Patients Treated With Proton Therapy for Brain and Skull Base Tumors. Int $J$ Radiat Oncol Biol Phys. 2018;101(4):854-859.

36. Ullrich NJ, Robertson R, Kinnamon DD, Scott RM, Kieran MW, Turner CD, Chi SN, Goumnerova L, Proctor M, Tarbell NJ, Marcus KJ, Pomeroy SL. Moyamoya following cranial irradiation for primary brain tumors in children. Neurology. 2007;68(12):932-938.

37. Kalapatapu VR, Shelton KR, Ali AT, Moursi MM, Eidt JF. Pseudoaneurysm: A review. Curr Treat Options Cardiovasc Med. 2008;10(2):173-183.

38. Tatsi C, Flippo C, Stratakis CA. Cushing syndrome: old and new genes. Best Practice \& Research Clinical Endocrinology \& Metabolism. 2020:101418.

39. Schultz KAP, Williams GM, Kamihara J, Stewart DR, Harris AK, Bauer AJ, Turner J, Shah R, Schneider K, Schneider KW, Carr AG, Harney LA, Baldinger S, Frazier AL, Orbach D, Schneider DT, Malkin D, Dehner LP, Messinger YH, Hill A. DICER1 and associated conditions: Identification of at-risk individuals and recommended surveillance strategies. Clin Cancer Res. 2018;24(10):2251-2261.

40. van Engelen K, Villani A, Wasserman JD, Aronoff $L$, Greer MLC, Tijerin Bueno M, Gallinger B, Kim RH, Grant R, Meyn MS. DICER1 syndrome: approach to testing and management at a large pediatric tertiary care center. Pediatr Blood Cancer. 2018;65(1):e26720.

41. Brown RJ, Kelly MH, Collins MT. Cushing syndrome in the McCune-Albright syndrome. J Clin Endocrinol Metab. 2010;95(4):1508-1515.

42. Golden T, Siordia JA. Osteochondromyxoma: Review of a rare carney complex criterion. Journal of bone oncology. 2016;5(4):194-197.

43. Correa R, Salpea $P$, Stratakis CA. Carney complex: an update. Eur J Endocrinol. 2015;173(4):M85-97.

44. Liu APY, Gudenas B, Lin T, Orr BA, Klimo P, Kumar R, Bouffet E, Gururangan S, Crawford JR, Kellie SJ, Chintagumpala M, Fisher MJ, Bowers DC, Hassall T, Indelicato DJ, Onar-Thomas A, Ellison DW, Boop FA, Merchant TE, Robinson GW, Northcott PA, Gajjar A. Risk-adapted therapy and biological heterogeneity in pineoblastoma: integrated clinico-pathological analysis from 
the prospective, multi-center SJMB03 and SJYC07 trials. Acta Neuropathol. 2019;139(2):259-271.

45. Li BK, Vasiljevic A, Dufour C, Yao F, Ho BLB, Lu M, Hwang EI, Gururangan S, Hansford JR, Fouladi M, Nobusawa S, Laquerriere A, Delisle MB, Fangusaro J, Forest F, Toledano H, Solano-Paez P, Leary S, Birks D, Hoffman LM, Szathmari A, Faure-Conter C, Fan X, Catchpoole D, Zhou L, Schultz KAP, Ichimura K, Gauchotte G, Jabado N, Jones C, Loussouarn D, Mokhtari K, Rousseau A, Ziegler DS, Tanaka S, Pomeroy SL, Gajjar A, Ramaswamy V, Hawkins C, Grundy RG, Hill DA, Bouffet E, Huang A, Jouvet A. Pineoblastoma segregates into molecular sub-groups with distinct clinico-pathologic features: a Rare Brain Tumor Consortium registry study. Acta Neuropathol. 2019;139(2):223241.

46. de Kock L, Sabbaghian N, Druker H, Weber E, Hamel N, Miller S, Choong CS, Gottardo NG, Kees UR, Rednam SP. Germ-line and somatic DICER1 mutations in pineoblastoma. Acta Neuropathol. 2014;128(4):583-595.

47. Sabbaghian N, Hamel N, Srivastava A, Albrecht S, Priest JR, Foulkes WD. Germline DICER1 mutation and associated loss of heterozygosity in a pineoblastoma. J Med Genet. 2012;49(7):417-419.

48. Pfaff E, Aichmüller $C$, Sill M, Stichel D, Snuderl M, Karajannis MA, Schuhmann MU, Schittenhelm J, Hasselblatt M, Thomas C, Korshunov A, Rhizova M, Wittmann A, Kaufhold A, Iskar M, Ketteler P, Lohmann D, Orr BA, Ellison DW, von Hoff K, Mynarek M, Rutkowski S, Sahm F, von Deimling A, Lichter P, Kool M, Zapatka M, Pfister SM, Jones DTW. Molecular subgrouping of primary pineal parenchymal tumors reveals distinct subtypes correlated with clinical parameters and genetic alterations. Acta Neuropathol. 2019;139(2):243-257.

49. Koelsche $C$, Mynarek M, Schrimpf D, Bertero L, Serrano J, Sahm F, Reuss DE, Hou Y, Baumhoer D, VokuhI C, Flucke U, Petersen I, Bruck W, Rutkowski S, Zambrano SC, Garcia Leon JL, Diaz Coronado RY, Gessler M, Tirado OM, Mora J, Alonso J, Garcia Del Muro X, Esteller M, Sturm D, Ecker J, Milde T, Pfister SM, Korshunov A, Snuderl M, Mechtersheimer G, Schuller U, Jones DTW, von Deimling A. Primary intracranial spindle cell sarcoma with rhabdomyosarcoma-like features share a highly distinct methylation profile and DICER1 mutations. Acta Neuropathol. 2018;136(2):327-337.

50. Uro-Coste E, Masliah-Planchon J, Siegfried A, Blanluet M, Lambo S, Kool M, Roujeau T, Boetto S, Palenzuela G, Bertozzi AI, Gambart M, Coupier I, OliverPetit I, Golmard L, Julia S, Savagner F, Mohand-Oumoussa B, TauziedeEspariat A, Delisle MB, Figarella-Branger D, Bourdeaut F, Rigau V. ETMR-like infantile cerebellar embryonal tumors in the extended morphologic spectrum of DICER1-related tumors. Acta Neuropathol. 2019;137(1):175-177.

51. Lambo S, Gröbner SN, Rausch T, Waszak SM, Schmidt C, Gorthi A, Romero JC, Mauermann M, Brabetz S, Krausert S, Buchhalter I, Koster J, Zwijnenburg DA, Sill M, Hübner J-M, Mack N, Schwalm B, Ryzhova M, Hovestadt V, PapillonCavanagh S, Chan JA, Landgraf P, Ho B, Milde T, Witt O, Ecker J, Sahm F, Sumerauer D, Ellison DW, Orr BA, Darabi A, Haberler C, Figarella-Branger D, Wesseling $P$, Schittenhelm J, Remke M, Taylor MD, Gil-da-Costa MJ, tastowska M, Grajkowska W, Hasselblatt M, Hauser P, Pietsch T, Uro-Coste E, Bourdeaut F, Masliah-Planchon J, Rigau V, Alexandrescu S, Wolf S, Li X-N, Schüller U, Snuderl M, Karajannis MA, Giangaspero F, Jabado N, von Deimling A, Jones DTW, Korbel JO, von Hoff K, Lichter P, Huang A, Bishop AJR, Pfister SM, Korshunov A, Kool M. The molecular landscape of ETMR at diagnosis and relapse. Nature. 2019;576(7786):274-280. 
1 


\section{$1 \quad$ Table Titles}

2 Table 1. Clinical profiles, treatments, and outcomes for patients with pituitary blastoma.

3 Table 2. Endocrine status at diagnosis and follow-up for 17 pituitary blastoma cases

4

\section{$5 \quad$ Figure Legends}

6 Figure 1. Growth charts depicting trends in body weight and length/height in pituitary blastoma

7 patients having (A) normal pituitary function, (B) panhypopituitarism with and (C) without growth

8 hormone replacement prediagnosis and postdiagnosis, including long-term follow-up. Chemo,

9 chemotherapy; GH, growth hormone; No., number.

10 Figure 2. Extent of resection, adjuvant therapy, and outcomes for the cohort. GTR, gross total

11 resection; NTR, near total resection; STR, subtotal resection; NED, no evidence of disease; RT,

12 radiation therapy.

13 Figure 3. Event-free survival (EFS) and overall survival (OS, A-B) in the entire cohort, (C-D) by

14 extent of surgery, and (E-F) period of diagnosis. Bx, biopsy; GTR, gross total resection; NTR, near

15 total resection; STR, subtotal resection. 
Table 1. Clinical profiles, treatments, and outcomes for patients with pituitary blastoma.

\begin{tabular}{|c|c|c|c|c|c|c|c|c|c|}
\hline $\begin{array}{l}\text { Patient number } \\
\text { (year of } \mathrm{Dx} \text { ) }\end{array}$ & Sex & $\begin{array}{c}\text { Age at } \\
\text { presentation/ } \\
\text { diagnosis }(\mathrm{m})\end{array}$ & $\begin{array}{l}\text { Tumor size } \\
\quad(\mathrm{cm})\end{array}$ & $\begin{array}{l}\text { Ki-67/ } \\
\text { MIB-1 }\end{array}$ & Treatment course & Progression & Latest disease status & $\begin{array}{l}\text { Duration } \\
\text { of FU }\end{array}$ & $\begin{array}{c}\text { First } \\
\text { publication }\end{array}$ \\
\hline $\begin{array}{c}1 \\
(2000)\end{array}$ & $\mathrm{F}$ & $13 / 13$ & 3.5 & $1.5 \%-39 \%$ & STR & No & Died of early complication & $1.5 \mathrm{~m}$ & [1] \\
\hline $\begin{array}{c}2 \\
(2006)\end{array}$ & $\mathrm{F}$ & $22 / 24$ & 4 & $1.6 \%$ & STR -> gamma knife (45 Gy) & No & Alive with NED & $14 \mathrm{y}$ & [27] \\
\hline $\begin{array}{c}3 \\
(2010)\end{array}$ & M & 9/9 & $3 \times 2.3 \times 1.6$ & $15 \%-50 \%$ & STR $->$ chemotherapy (baby POG) & No & Alive with stable lesion & $10 y$ & {$[28]^{*}$} \\
\hline $\begin{array}{c}4 \\
(2006)\end{array}$ & $\mathrm{F}$ & $18 / 24$ & $\begin{array}{l}2.4 \times 3.1 \times \\
2.4\end{array}$ & Not reported & GTR & No & Alive with NED & $13.6 \mathrm{y}$ & [20] \\
\hline $\begin{array}{c}5 \\
(2009)\end{array}$ & $\mathrm{F}$ & $13 / 13$ & $2.1 \times 1.8$ & $60 \%$ & STR $->$ chemotherapy (TMZ) $->$ PD & $\begin{array}{c}\text { Local - } 20 \text { months from diagnosis } \\
\text { (focal RT } 54 \text { Gy -> TMZ -> BEV, CPT- } \\
11 \text {-> IFOS, CARBO, VP16) }\end{array}$ & $\begin{array}{l}\text { Died of aneurysmal } \\
\text { bleeding }\end{array}$ & $5.5 y$ & [2] \\
\hline $\begin{array}{c}6 \\
(2005)\end{array}$ & M & $5 / 7$ & $\mathrm{~N} / \mathrm{A}$ & Not reported & $\mathrm{Bx}$ & No & Died of early complication & $1.3 \mathrm{~m}$ & [4] \\
\hline $\begin{array}{c}7 \\
(1980)\end{array}$ & M & $6 / 11$ & 3 & Not reported & STR -> GTR & No & $\begin{array}{l}\text { Died of second brain } \\
\text { tumor (?pineoblastoma) }\end{array}$ & $2.3 y$ & [23] \\
\hline $\begin{array}{c}8 \\
(1977)\end{array}$ & $\mathrm{M}$ & $8 / 8$ & $12 \times 8 \times 5$ & Low & $B x->S T R$ & No & Died of early complication & $1 \mathrm{~d}$ & [24] \\
\hline $\begin{array}{c}9 \\
(1996)\end{array}$ & $\mathrm{F}$ & $5 / 7$ & $3 \times 2 \times 2$ & Not reported & GTR & No & Alive with NED & $23.5 y$ & [25] \\
\hline $\begin{array}{c}10 \\
(1994)\end{array}$ & $\mathrm{F}$ & ?/12 & $6 \times 4 \times 4$ & Not reported & STR & Local - 18 months from diagnosis & Died of progression & $1.5 \mathrm{y}$ & [26] \\
\hline $\begin{array}{c}11 \\
(2012)\end{array}$ & $\mathrm{F}$ & $7 / 7$ & $\mathrm{~N} / \mathrm{A}$ & $\begin{array}{l}\text { Markedly } \\
\text { proliferative }\end{array}$ & STR $->$ STR & No & Alive with stable lesion & $8.2 y$ & [4] \\
\hline $\begin{array}{c}12 \\
(2012)\end{array}$ & M & $8 / 13$ & $\mathrm{~N} / \mathrm{A}$ & $\begin{array}{l}\text { Markedly } \\
\text { proliferative }\end{array}$ & $\begin{array}{c}\text { Bx -> chemotherapy (TMZ) -> NTR -> } \\
\text { chemotherapy (TMZ) }\end{array}$ & No & Alive with NED & $7.8 \mathrm{y}$ & [4] \\
\hline $\begin{array}{c}13 \\
(2000)\end{array}$ & $\mathrm{F}$ & 9/9 & $1.7 \times 1.5$ & Moderate & $\begin{array}{c}\text { GTR -> chemotherapy (ANZCCSG baby brain } \\
\text { protocol without ASCT) }\end{array}$ & No & Alive with NED & 19 y & [4] \\
\hline $\begin{array}{c}14 \\
\text { (pub. 2014) }\end{array}$ & $\mathrm{F}$ & $11 / 12$ & $2.9 \times 2 \times 2.8$ & Up to $20 \%$ & $\begin{array}{c}\text { STR -> chemotherapy (CPM, VCR, MTX, CARBO, } \\
\text { VP16) }\end{array}$ & No & $\begin{array}{l}\text { Died of catheter-related } \\
\text { complication }\end{array}$ & $4 m$ & [3] \\
\hline $\begin{array}{c}15 \\
(2012)\end{array}$ & M & $8 / 10$ & $\begin{array}{c}2.6 \times 2.4 \times \\
2.4\end{array}$ & $19 \%$ & GTR & No & Alive with NED & $8.4 \mathrm{y}$ & [18] \\
\hline $\begin{array}{c}16 \\
(2014)\end{array}$ & M & $16 / 22$ & 2 & $10-15 \%$ & GTR & No & Alive with NED & $6.7 y$ & [17] \\
\hline $\begin{array}{c}17 \\
(2009)\end{array}$ & $\mathrm{F}$ & $1 / 2$ & $5 \times 3 \times 2$ & $\begin{array}{c}2-3 \% \text { (focally } \\
\text { higher) }\end{array}$ & STR & No & Died of sepsis & $1 \mathrm{~m}$ & [16] \\
\hline
\end{tabular}

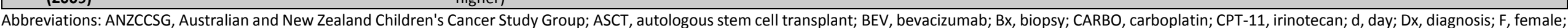

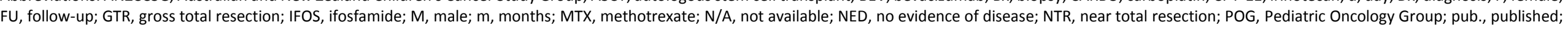
$R T$, radiotherapy; STR, subtotal resection; TMZ, temozolomide; VCR, vincristine; VP16, etoposide; y, years.

*Reference [28] is an abstract; full case description appears in reference [2]: "present case 1". 
Table 2. Endocrine status at diagnosis and follow-up for 17 pituitary blastoma cases

\begin{tabular}{|c|c|c|c|c|c|c|c|c|c|c|c|c|c|c|c|}
\hline \multirow{2}{*}{$\begin{array}{l}\text { Patient } \\
\text { number }\end{array}$} & \multirow{2}{*}{$\begin{array}{l}\text { Age at } \\
\text { Dx }\end{array}$} & \multirow{2}{*}{$\begin{array}{l}\text { Age at } \\
\text { last FU }\end{array}$} & \multirow{2}{*}{$\begin{array}{l}\text { Tumor } \\
\text { ACTH IHC }\end{array}$} & \multirow{2}{*}{$\begin{array}{c}\text { Tumor GH } \\
\text { IHC }\end{array}$} & \multirow{2}{*}{$\begin{array}{c}\text { Clinically } \\
\text { Cushingoid at } \\
\text { Dx }\end{array}$} & \multicolumn{2}{|c|}{ Adrenal axis } & \multicolumn{2}{|c|}{ Thyroid axis } & \multicolumn{2}{|c|}{ Somatotropic/growth axis } & \multicolumn{2}{|c|}{ Gonadal axis } & \multicolumn{2}{|c|}{ Diabetes insipidus } \\
\hline & & & & & & Dx & FU & Dx & FU & Dx & FU & Dx & FU & Dx & FU \\
\hline \multicolumn{16}{|c|}{ Patients alive at last FU } \\
\hline 2 & $24 m$ & $16 y$ & + & + & No & $\begin{array}{c}\text { ACTH } \uparrow \\
\text { Random serum } \\
\text { cortisol } \mathrm{nl}\end{array}$ & $\mathrm{ACTH} \downarrow$ & $\mathrm{nl}$ & TSH $\downarrow$ & $\begin{array}{l}\text { decreased linear growth } \\
<10 \%\end{array}$ & $\mathrm{GH} \downarrow$ & $\mathrm{nl}$ & $\downarrow$ & No & Yes \\
\hline 3 & $9 m$ & $10.8 y$ & + & - & $\begin{array}{l}\text { No (post- } \\
\text { operatively, } \\
\text { Cushing } \\
\text { features+) }\end{array}$ & $\begin{array}{c}\text { ACTH } \uparrow \\
\text { Failed DST }\end{array}$ & $\mathrm{nl}$ & TSH, fT4,TT3 $\downarrow$ & $\mathrm{nl}$ & $\mathrm{nl}$ & $\mathrm{nl}$ & $\mathrm{nl}$ & $\mathrm{nl}$ & No & No \\
\hline 4 & $24 \mathrm{~m}$ & $15.6 y$ & + & - & Yes & $\begin{array}{c}\text { ACTH个 } \\
\text { Failed DST }\end{array}$ & ACTH $\downarrow$ & unk & TSH $\downarrow$ & unk & $\mathrm{GH} \downarrow$ & $\mathrm{nl}$ & $\downarrow$ & No & $\begin{array}{c}\text { Transient } \\
\text { postoperatively }\end{array}$ \\
\hline 9 & $7 \mathrm{~m}$ & $24.1 y$ & + & + & Yes & ACTH $\uparrow$ & ACTH $\downarrow$ & $\mathrm{nl}$ & TSH $\downarrow$ & $\mathrm{nl}$ & $\mathrm{nl}$ & unk & $\downarrow$ & No & No \\
\hline 11 & $7 \mathrm{~m}$ & $8.8 y$ & + & + & No & unk & ACTH $\downarrow$ & unk & TSH $\downarrow$ & unk & $\mathrm{GH} \downarrow$ & unk & $\mathrm{nl}$ & unk & Yes \\
\hline 12 & $13 \mathrm{~m}$ & $8.9 y$ & + & + & Yes & $\begin{array}{c}\text { ACTH } \uparrow \\
\text { Failed DST }\end{array}$ & $\mathrm{nl}$ & unk & $\mathrm{nl}$ & unk & $\begin{array}{c}\text { decreased linear } \\
\text { growth but unk for } \\
\text { GHD }\end{array}$ & unk & $\mathrm{nl}$ & No & No \\
\hline 13 & $9 \mathrm{~m}$ & $19.8 y$ & - & - & No & unk & ACTH $\downarrow$ & unk & TSH $\downarrow$ & unk & $\mathrm{GH} \downarrow$ & unk & $\downarrow$ & No & Yes \\
\hline 15 & $10 \mathrm{~m}$ & $9.2 y$ & + & $\begin{array}{l}\text { Not } \\
\text { reported }\end{array}$ & Yes & $\begin{array}{c}\text { ACTH } \uparrow \\
\text { Random serum } \\
\text { cortisol } \uparrow\end{array}$ & ACTH $\downarrow$ & unk & TSH $\downarrow$ & unk & $\mathrm{GH} \downarrow$ & unk & $\mathrm{nl}$ & No & No \\
\hline 16 & $22 m$ & $8.5 y$ & + & $\begin{array}{l}\text { Not } \\
\text { reported }\end{array}$ & No & ACTH $\mathrm{nl}$ & ACTH $\downarrow$ & $\mathrm{nl}$ & TSH $\downarrow$ & $\mathrm{nl}$ & $\mathrm{GH} \downarrow$ & unk & $\mathrm{nl}$ & No & No \\
\hline \multicolumn{16}{|c|}{ Deceased patients } \\
\hline 1 & $13 m$ & $14.5 \mathrm{~m}$ & + & + & Yes & $\begin{array}{c}\text { ACTH } \uparrow \\
\text { Failed DST }\end{array}$ & - & TSH $\downarrow$ & - & $\mathrm{nl}$ & - & $\mathrm{nl}$ & - & Yes & - \\
\hline 5 & $13 \mathrm{~m}$ & $6.9 y$ & + & + & No & unk & $\mathrm{nl}$ & $\mathrm{nl}$ & $\mathrm{nl}$ & $\mathrm{nl}$ & $\mathrm{nl}$ & unk & $\mathrm{nl}$ & No & No \\
\hline 6 & $7 m$ & $8.3 m$ & + & + & No & unk & - & $\mathrm{nl}$ & - & $\mathrm{nl}$ & - & $\mathrm{nl}$ & - & No & - \\
\hline 7 & $11 \mathrm{~m}$ & $3.2 y$ & + & - & Yes & $\begin{array}{c}\mathrm{ACTH} \uparrow \\
\text { Urine cortisol } \uparrow\end{array}$ & ACTH $\downarrow$ & $\mathrm{nl}$ & TSH $\downarrow$ & $\mathrm{nl}$ & unk & unk & unk & No & Yes \\
\hline 8 & $8 m$ & $8 m$ & + & + & Yes & $\begin{array}{c}\text { ACTH } \uparrow \\
\text { Failed DST }\end{array}$ & - & TSH $\downarrow$ & - & unk & - & $\mathrm{nl}$ & - & No & - \\
\hline 10 & $12 m$ & $2.5 y$ & + & + & Yes & $\begin{array}{l}\text { Random serum } \\
\text { cortisol } \uparrow\end{array}$ & - & unk & - & $\begin{array}{l}\text { decreased linear growth } \\
\qquad 10 \%\end{array}$ & - & unk & - & Yes & - \\
\hline 14 & $12 \mathrm{~m}$ & $16 \mathrm{~m}$ & + & $\begin{array}{l}\text { Not } \\
\text { reported }\end{array}$ & Yes & $\begin{array}{c}\text { ACTH } \uparrow \\
\text { Failed DST }\end{array}$ & - & $\mathrm{nl}$ & - & $\mathrm{nl}$ & - & unk & - & No & - \\
\hline 17 & $2 m$ & $3 \mathrm{~m}$ & + & + & Yes & $\begin{array}{c}\text { ACTH个 } \\
\text { Failed DST }\end{array}$ & - & $\mathrm{nl}$ & - & $\mathrm{nl}$ & - & $\mathrm{nl}$ & - & No & $\begin{array}{c}\text { Transient } \\
\text { postoperatively }\end{array}$ \\
\hline
\end{tabular}

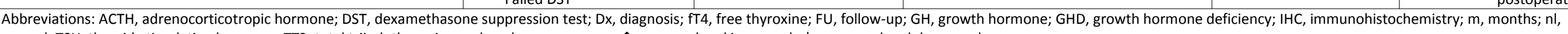
normal; TSH, thyroid-stimulating hormone; TT3, total triiodothyronine; unk, unknown; $y$, years; $\uparrow$ measured and increased; $\downarrow$ measured and decreased. 
A

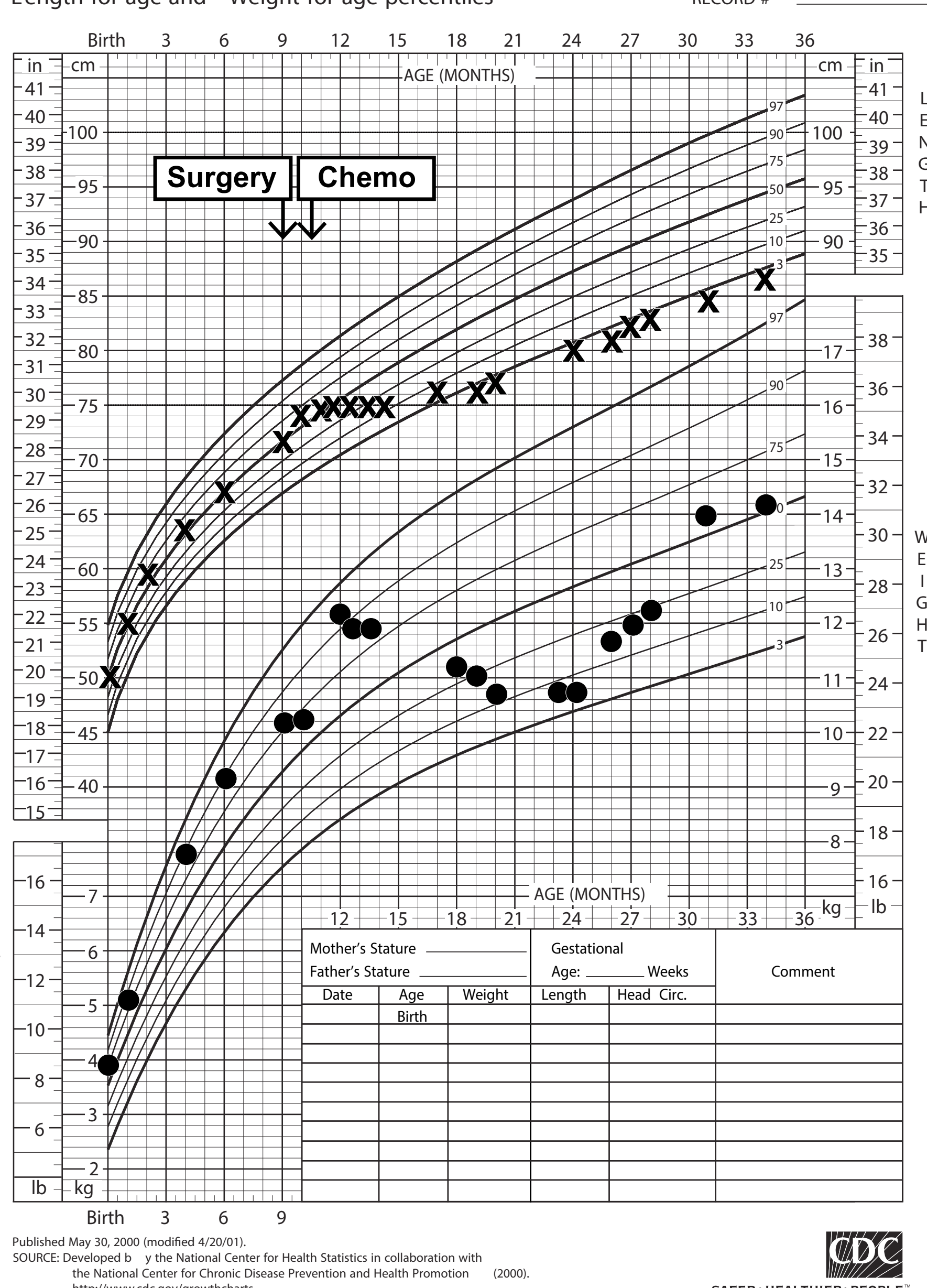

B

Birth to 36 months: Girls

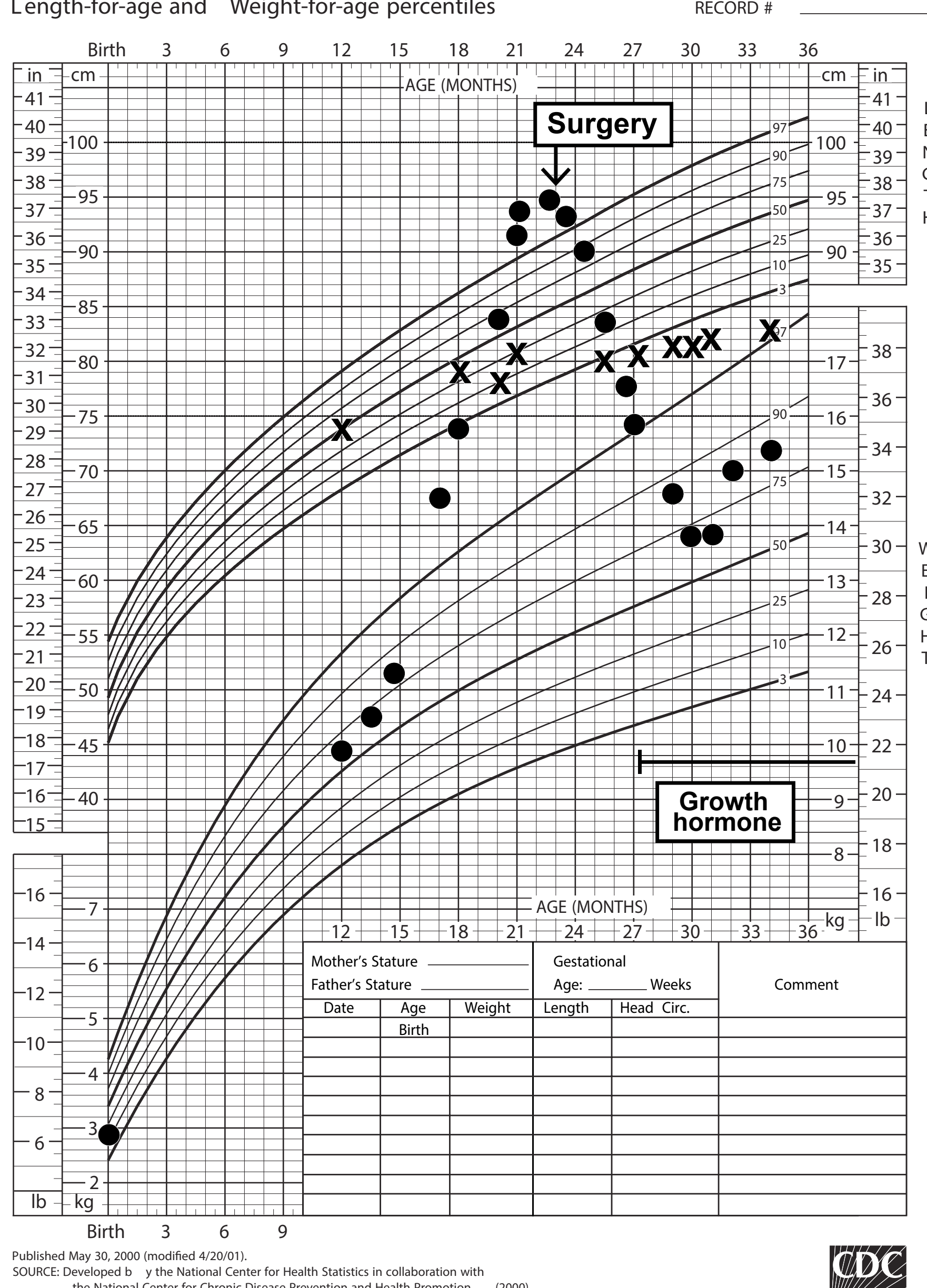

C
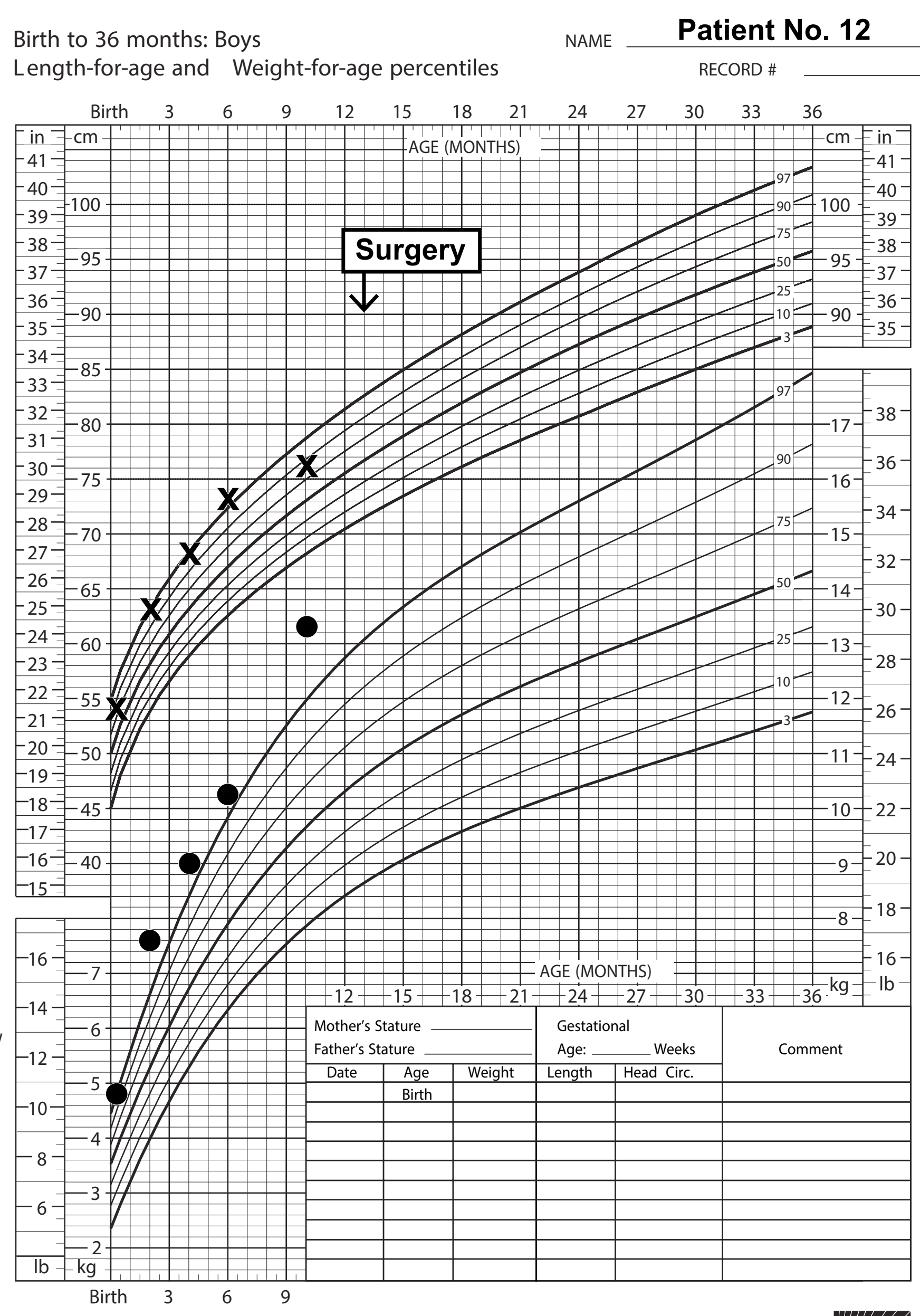

2 to 20 years: Boys Name Patient No. 3
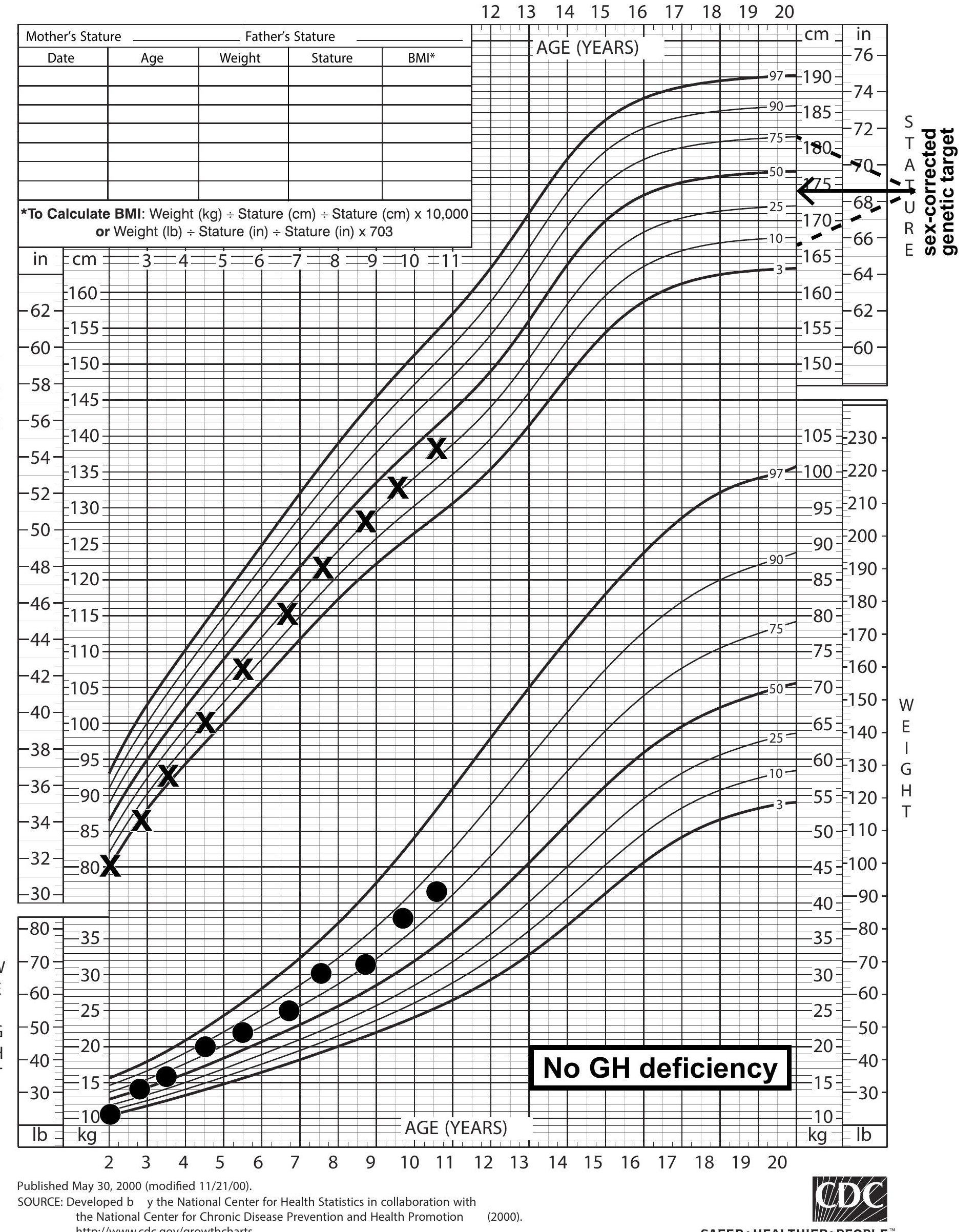

tore

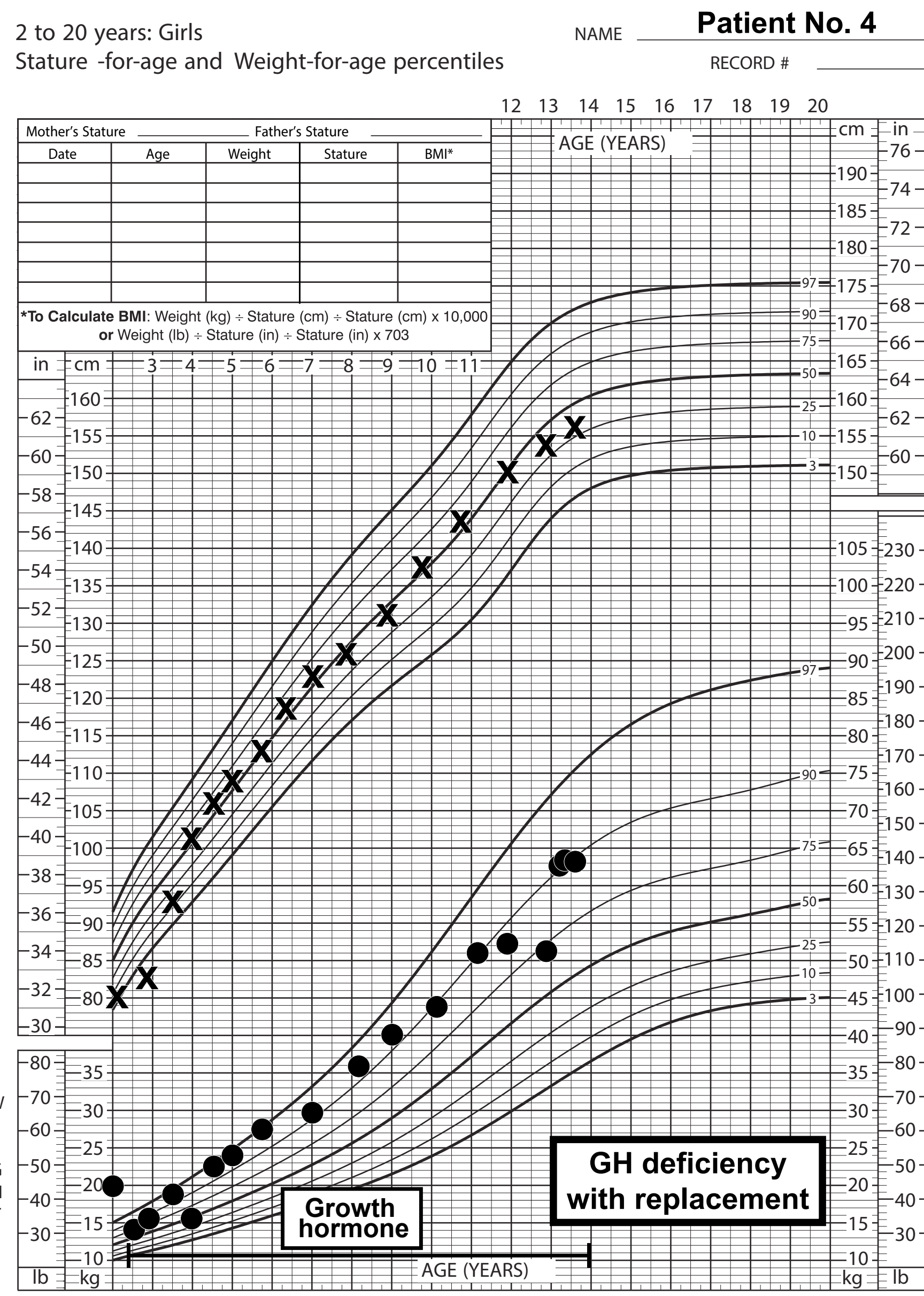

rope

2 to 20 years: Boys Name Patient No. 12

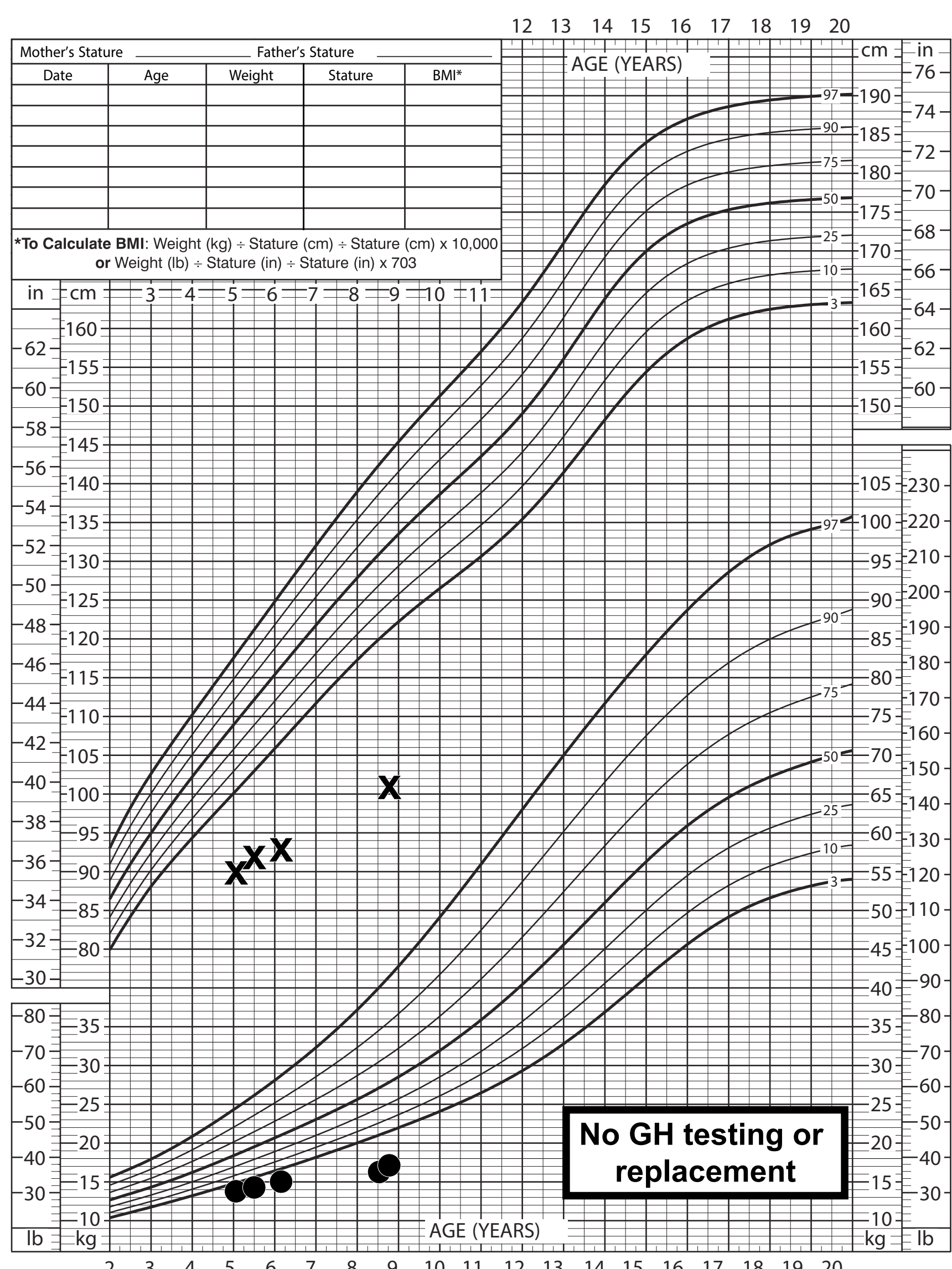

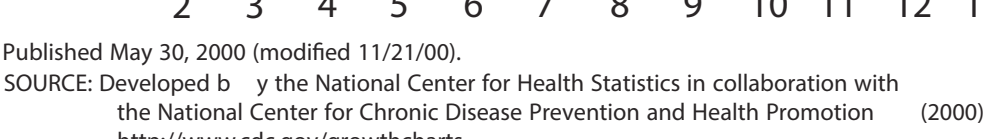




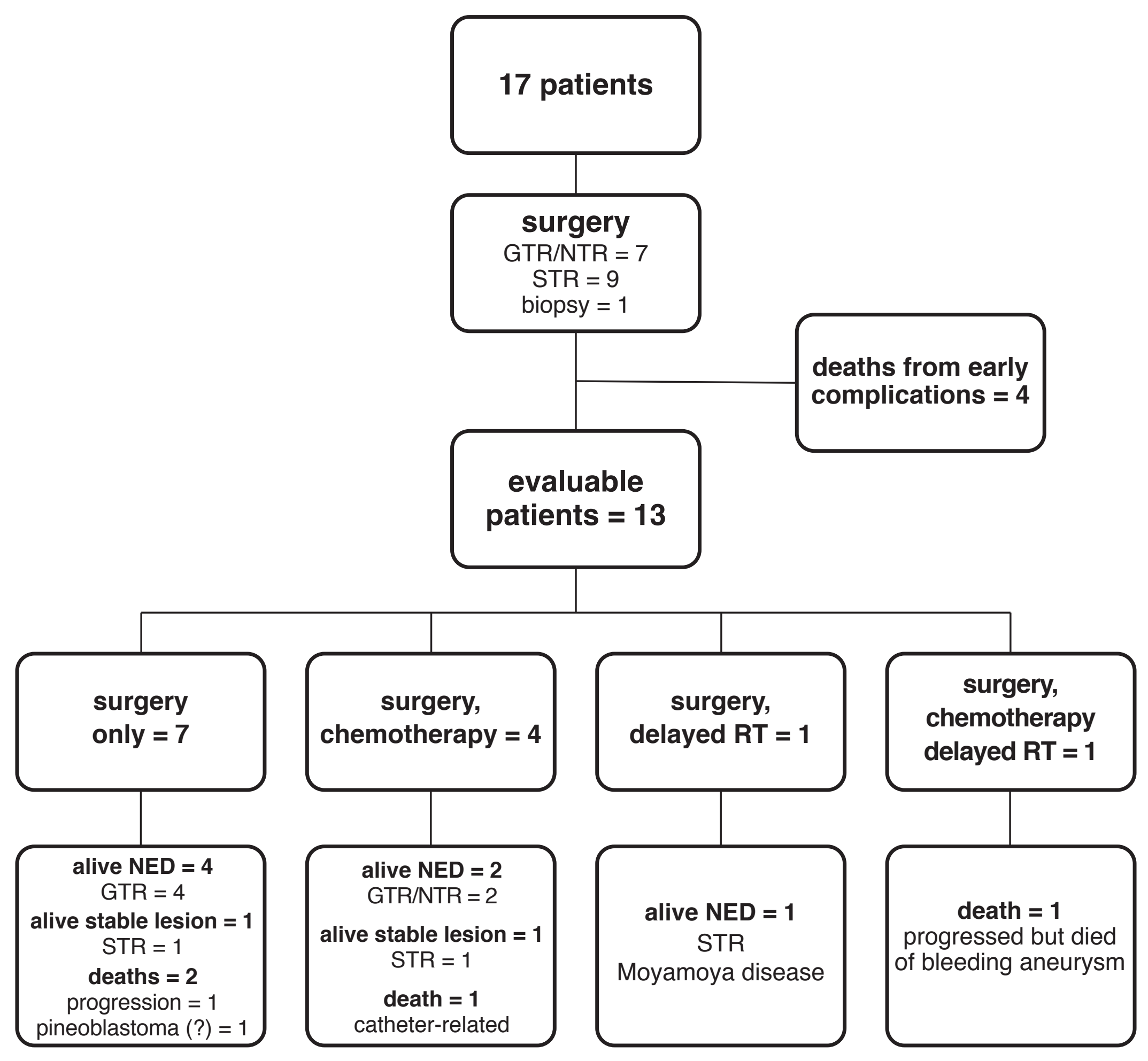

evaluable

patients $=13$ table lesion $=1$ STR $=1$

deaths $=2$

progression = catheter-related 


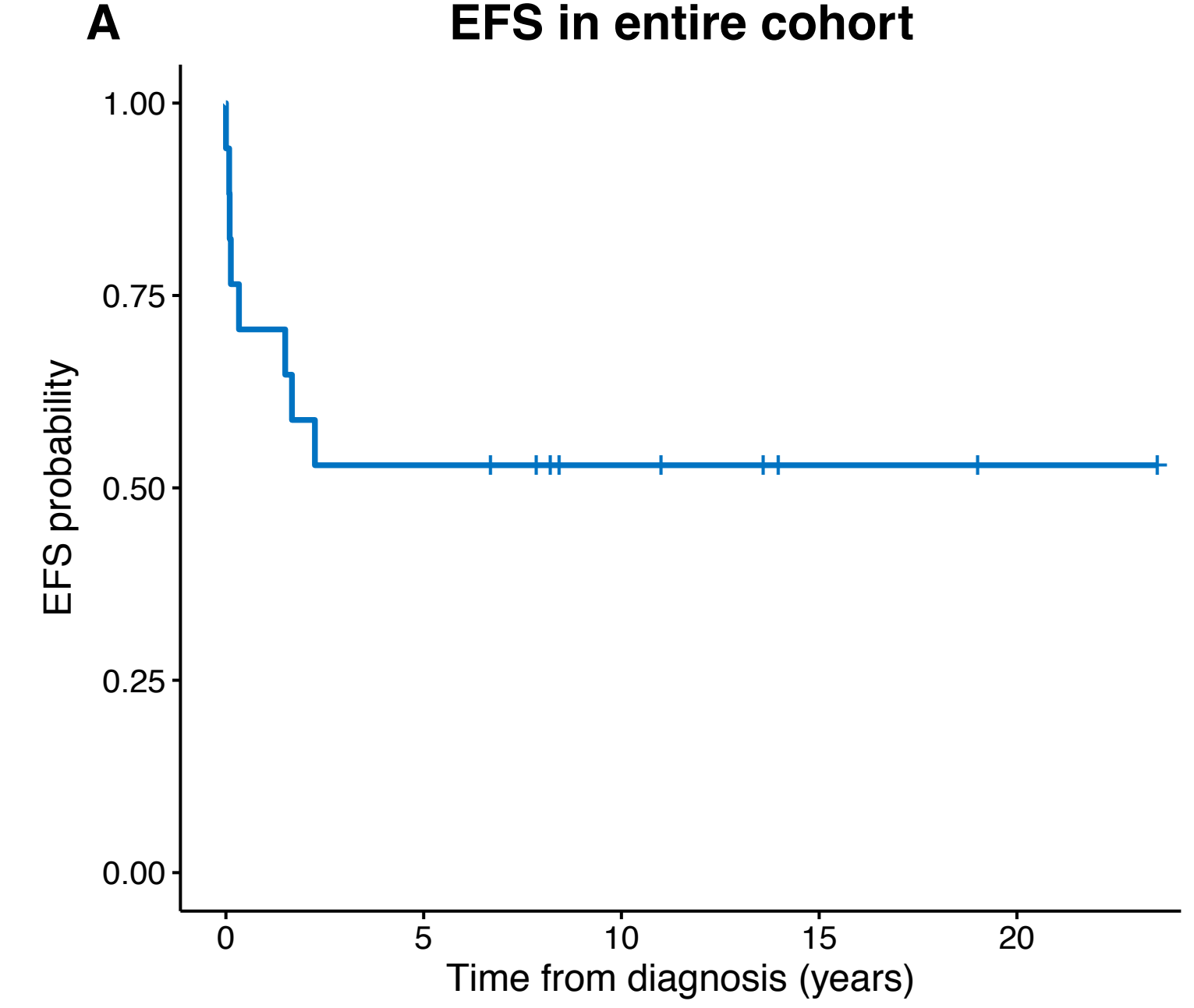

Number at risk

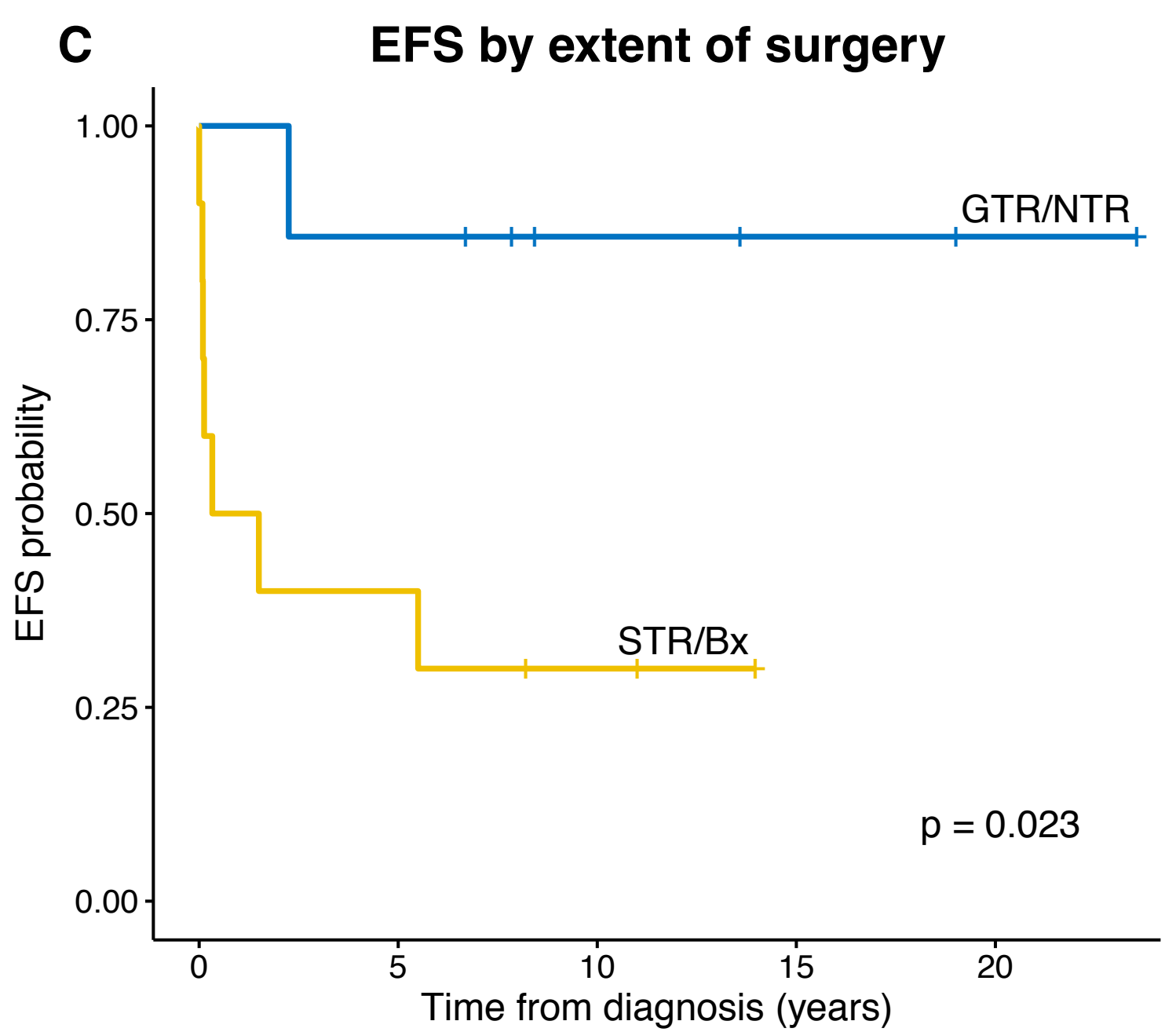

Number at risk
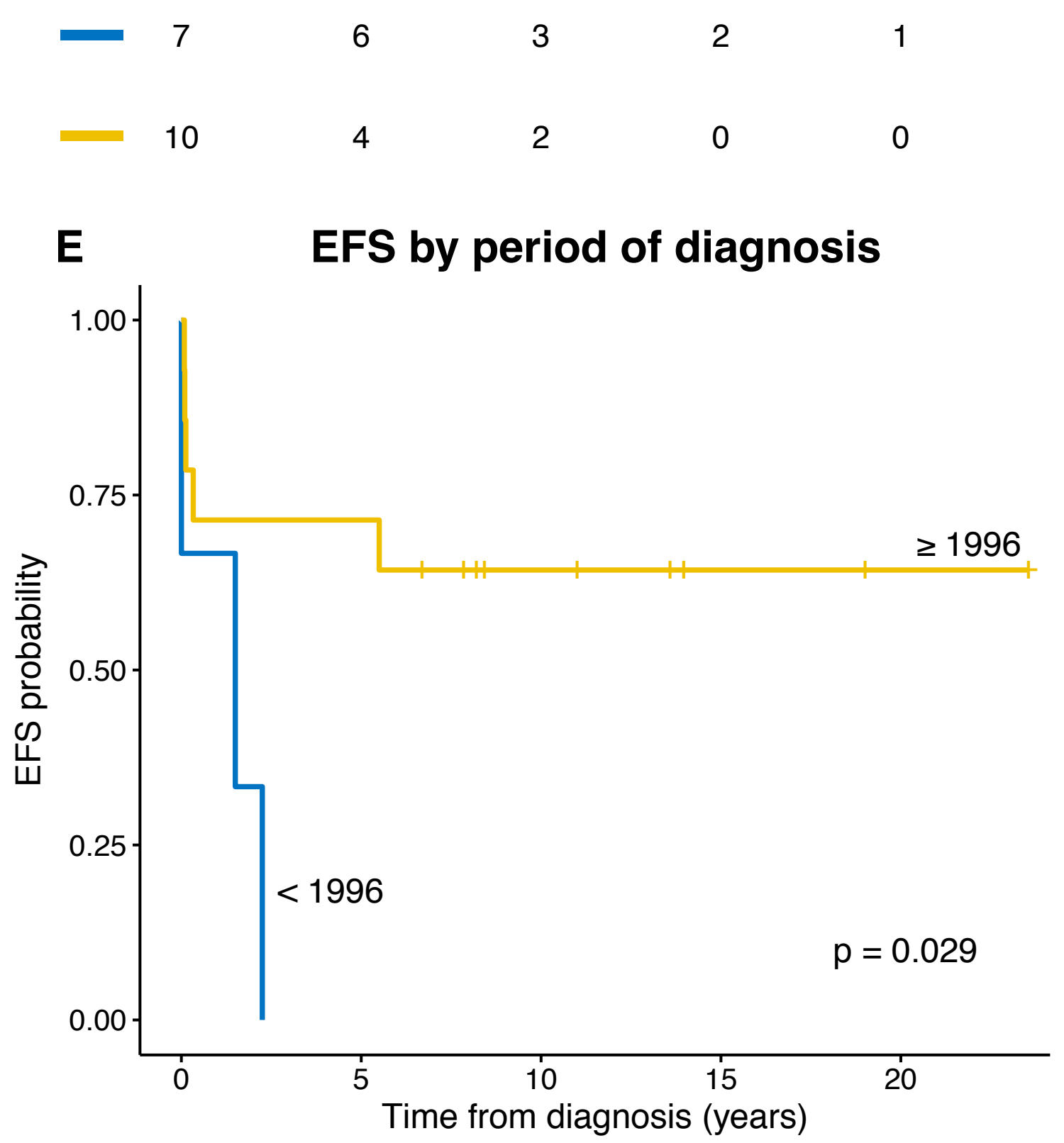

Number at risk
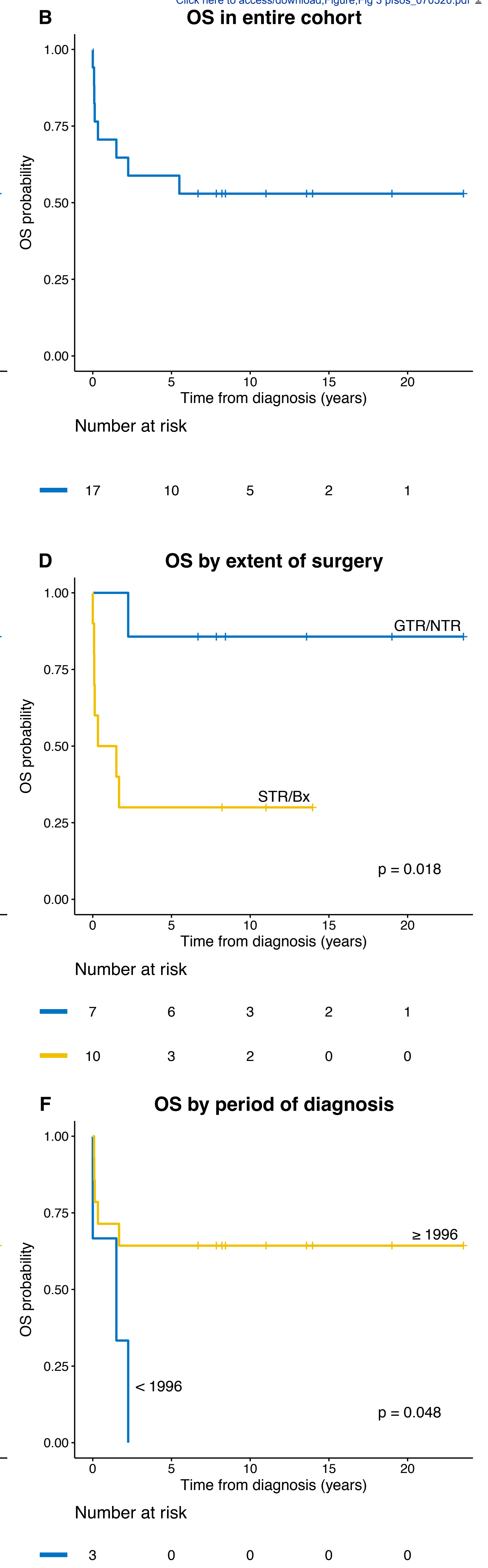

- 3
Number at risk

Number at risk

Number at risk

Number at risk
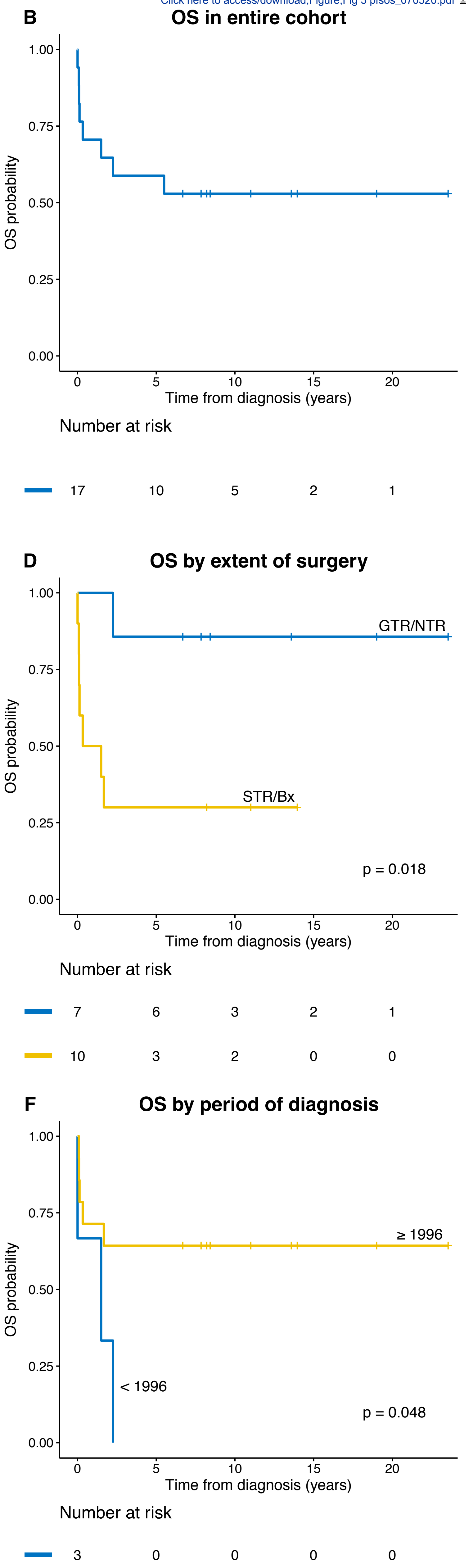

$0 \quad 0 \quad 0$

$$
14
$$

